\title{
Congenital fiber-type disproportion myopathy
}

INSERM

\section{Source}

INSERM. (1999). Orphanet: an online rare disease and orphan drug data base. Congenital fiber-type disproportion myopathy. ORPHA:2020

Cong enital fiber type disproportion myopathy (CFT DM) is a rare type of myopathy characterized by hypotonia and mild to severe generalized muscle weakness present at birth or within the first year of life. 